JURNAL KESEHATAN GIGI

(Dental Health Journal)

Vol. 7 No.1 Pebruari 2020

\title{
EFFECTIVENESS OF EXTENSION WITH DENTAL HEALTH EDUCATION VIDEO MEDIA ON ORAL HYGIENE AND SKILL CLEANING LEVELS IN DENTAL TUNAGRAHITA STUDENTS IN SLB BALI PROVINCE
}

I Gede Surya Kencana ${ }^{1}$, I Made Budi Artawa ${ }^{2}$, Ida Ayu Dewi Kumala Ratih ${ }^{3}$, IGA Raiyanti ${ }^{4}$

1,2,3 Dosen Jurusan Kesehatan Gigi menkes Denpasar

igedesuryakencana65@gmail.com

imadebudiartawa@gmail.com

\begin{abstract}
Dental health is one of most important things for childrens growth, but in Indonesia there are not many parents who care about childrens dental health, especially in childrens with special needs (disabled children). Childrens with special needs have a higher risk of oral and dental health problems, because they have mental and physical shortcomings and limitations to perform optimal self-cleaning teeth. The purpose of this study was to determine the effectiveness of counseling with Dental Health Education video media on tooth brushing behavior and the level of oral and dental hygiene in middle-class mental retirement students in the province of Bali in 2019. This type of research is an experimental community trial with pretest-posttest control group design. The results of research on Tunagrahita students are in the medium category of SLB in Bali Province as many as 200 people. The education level of the respondents consisted of SDLB, SMPLB and SMALB. Students' skills in brushing their teeth before the intervention in the treatment group $100(100 \%)$ need guidance, after the intervention $6(6 \%)$ categories are good, 13 students in the sufficient category and 81 (81\%) need guidance. The level of dental hygiene of retarded students was in the moderate category in the treatment group before the intervention with good criteria 15 people, moderate 68 (68\%) and bad criterial7 (17\%), after the intervention with good criteria 36 (68\%), moderate $56(56 \%)$ and bad criteria $8(8 \%)$. The average level of dental hygiene in the treatment group before the intervention was 2.26 and after the intervention 1.87. The Wilcoxon Signed Rank Test statistic results showed that the analysis results obtained a p value (Asymp.sig 2 tailed) of 0,000 less than 0.05. Conclusion there are significant differences in both the skills and oral and dental hygiene in the treatment group and the control group after the intervention is given.
\end{abstract}

Keywords: Students with intellectual disabilities, tooth brushing skills, dental hygiene

\section{Pendahuluan}

Dalam dunia pendidikan ditemukan anak-anak yang memiliki kecerdasan di atas rata-rata anak pada umumnya dan cepat dalam belajar. Disamping itu, ada juga anakanak yang memiliki kecerdasan dibawah ratarata pada umumnya. Anak-anak yang memiliki kecerdasan dibawah rata-rata pada umumnya disebut anak terbelakang mental (mentally retarded), istilah resmi yang digunakan di Indonesia adalah anak tunagrahita. MenurutEfendi dalam Nunung Apriyanto, anak tunagrahita adalah anak yang mengalami taraf kecerdasan yang rendah sehingga untuk meniti tugas perkembangan mereka sangat membutuhkan layanan pendidikan dan bimbingan secara khusus ${ }^{8}$.

$$
\text { Data Riset Kesehatan Dasar }
$$

(Riskesdas) tahun 2013, menunjukkan bahwa anak usia 10-14 tahun di Propinsi Bali sebesar $22,4 \%$ mengalami masalah kesehatan gigi dan mulut. Hanya 31,3 \% yang menerima pelayanan kesehatan gigi dari tenaga medis. Selanjutnya lulusan SLTP sebesar 24,4 \% mengalami masalah kesehatan gigi dan mulut, dan hanya $41,8 \%$ menerima pelayanan kesehatan gigi dari tenaga medis. Rata-rata Decay,Missing,Filling-Teeth (DMF-T) bagi 
penduduk yang lulusan SMP adalah 3,17. Angka tersebut jauh lebih tinggi dari target nasional yaitu $1^{2}$.

Hasil penelitian Novitasari (2011), keterampilan anak tunagrahita sedang dalam menggosok gigi dapat ditingkatkan melalui video. Hal ini dapat dibuktikan dari data hasil penelitian. Data hasil penelitian tersebut menggambarkan bahwa keterampilan menggosok gigi pada anak tunagrahita sedang (x) meningkat setelah diberikannya intervensi melalui video. ${ }^{6}$

Pemilihan media video pembelajaran pada anak tunagrahita diharapkan menimbulkan persepsi yang sama, dapat menarik sehingga lebih mudah bagi siswa tunagrahita untuk memusatkan perhatian, sehingga tidak mudah dilupakan. Media video dental health education ini nantinya dihubungkan dengan program khusus bina diri bagi anak tunagrahita, dimana program bina diri (self care skill) adalah program yang dipersiapkan agar siswa tunagrahita mampu menolong dirinya sendiri dalam bidang yang berkaitan kebutuhan diri sendiri ${ }^{4}$. Penggunaan media video dalam penyuluhan tentang cara cara menyikat gigi diharapkan memberikan dampak yang dapat menarik perhatian anak tunagrahita sehingga dapat diserap dan dipahami dengan baik ${ }^{4}$.

Menurut Green dan Vermillion, untuk mengukur kebersihan gigi dan mulut adalah dengan mempergunakan suatu indeks yang disebut Oral Higiene Index Simplified (OHI$S$ ). Nilai dari $O H I-S$ ini merupakan nilai yang diperoleh dari hasil penjumlahan antara debris indeks dan kalkulus indeks ${ }^{9}$.

Tujuan penelitian untuk mengetahui efektivitas penyuluhan dengan media video Dental Health Education terhadap Perilaku Menyikat Gigi dan tingkat kebersihan gigi dan mulut pada anak Tuna Grahita di SLB di provinsi Bali Tahun 2019.

Metode Jenis penelitian ini adalah Experimental community trial dengan pretest-postest control groupdesign, dalam hal ini adalah vidiodental health education untuk meningkatkan keterampilan menyikat gigi dan kebersihan gigi dan mulut anak Sekolah Luar Biasa (SLB).

Penelitian ini dilaksanakan di Sekolah Luar Biasa di Provinsi Bali. Waktu penelitian dilaksanakan mulai bulan Juni sampai dengan Bulan Nopember 2019. Jumlah sampel sebanyak 200 orang. Kriteria inklusi sampel dalam penelitian ini yaitu pada saat dilakukan penelitian sampel sebagai murid SLB di Provinsi Bali dan bersedia menjadi sampel atau diperiksa giginya. Kriteria ekslusi dalam penelitian ini adalah pada saat pemeriksaan kebersihan gigi dan mulut gigi indek tidak memenuhi syarat, tidak mendapatkan persetujuan dari orang tua, pada saat perlakukan responden yang tidak masuk sekolah maksimal 7 hari berturut-turut. Jika terjadi ketiga hal tersebut maka akan di keluarkan sebagai sampel.

Data dianalisis secara kuantitatif univariat, analisis efektivitas penyuluhan dengan media video Dental Health Education terhadap tingkat kebersihan gigi dan mulut pada siswa Tunagrahita kategori sedang di SLB Provinsi Bali, dilakukan dengan analisis perbedaan nilai $O H I-S$ sebelum dan sesudah diberikan intervensi baik pada kelompok perlakuan maupun kelompok kontrol. Untuk menentukan jenis analisis yang akan dipergunakan maka terlebih dahulu dilakukan uji normalitas data. Uji Normalitas data dilakukan dengan uji statistik Kolmogorov semirnov. Jika data normal maka dipergunakan uji paired T-test dan unpaired $T$-test dan jika data tidak normal maka dipergunakan Wilcoxon test dan Mann Whitney Test (Santoso, 2005).

\section{Hasil penelitian}

\section{Kondisi lokasi penelitian}

Penelitian tentang Efektivitas Penyuluhan dengan Media Video Dental Health Education terhadap Tingkat Kebersihan Gigi dan Keterampilan Menyikat Gigi pada Siswa Tuna Grahita di SLB di Provinsi Bali. 


\section{Karakteristik subyek penelitian}

a. Karakteristik subyek penelitian pada anak

Tunagrahita kategori sedang di Provinsi

Bali

Tabel 1 Karakteristik subyek penelitian pada anak Tunagrahita kategori sedang terhadap Kebersihan Gigi dan mulut di SLB Provinsi Bali Tahun 2019

\begin{tabular}{|c|c|c|c|c|c|c|c|c|c|c|c|c|c|c|c|}
\hline \multirow[t]{3}{*}{ Karakteristik } & & \multicolumn{7}{|c|}{ Kelompok Perlakuan } & \multicolumn{7}{|c|}{ Kelompok Kontrol } \\
\hline & & \multirow[t]{2}{*}{$\mathrm{Jml}$} & \multicolumn{2}{|c|}{ Baik } & \multicolumn{2}{|c|}{ Sedang } & \multicolumn{2}{|c|}{ Buruk } & \multirow[t]{2}{*}{ Jml } & \multicolumn{2}{|c|}{ Baik } & \multicolumn{2}{|c|}{ Sedang } & \multicolumn{2}{|c|}{ Buruk } \\
\hline & & & $\mathrm{F}$ & $\%$ & $\mathrm{~F}$ & $\%$ & $\mathrm{f}$ & $\%$ & & $\mathrm{f}$ & $\%$ & $f$ & $\%$ & $\mathrm{f}$ & $\%$ \\
\hline \multirow[t]{3}{*}{ Jenis Kelamin } & Laki & 63 & 11 & 17,4 & 40 & 63,4 & 12 & 19 & 64 & 17 & 26,6 & 45 & 70,3 & 2 & 3,1 \\
\hline & Perempuan & 37 & 5 & 13,5 & 25 & 67,5 & 7 & 18,9 & 36 & 2 & 5,6 & 32 & 88,8 & 2 & 5,6 \\
\hline & Total & 100 & 16 & & 65 & & 19 & & 100 & 19 & & 77 & & 4 & \\
\hline \multirow{4}{*}{$\begin{array}{l}\text { Tingkat } \\
\text { Pendidikan }\end{array}$} & SDLB & 49 & 11 & 22,4 & 34 & 69,4 & 4 & 8,2 & 59 & 6 & 10,2 & 51 & 86,4 & 2 & 3,4 \\
\hline & SMPLB & 35 & 3 & 8,6 & 21 & 60 & 11 & 31,4 & 27 & 3 & 11,1 & 22 & 81,5 & 2 & 7,4 \\
\hline & SMALB & 16 & 2 & 12,5 & 11 & 68,75 & 3 & 18,75 & 14 & 2 & & 12 & & & \\
\hline & Total & 100 & 16 & & 66 & & 18 & & 100 & 11 & & 85 & & 4 & \\
\hline
\end{tabular}

Tabel 1 menunjukkan bahwa berdasarkan jenis kelamin siswa pada kelompok perlakuan termasuk dalam kategori sedang untuk lakilaki sebanyak 40 orang $(63,4 \%)$ dan siswa perempuan sebanyak 25 orang $(67,5 \%)$ sedangkan pada kelompok kontrol termasuk dalam kategori sedang untuk laki-laki sebanyak 45 orang $(70,3 \%)$ dan siswa perempuan sebanyak 32 orang $(88,8 \%)$ sedangkan pada kelompok control.

a. Karakteristik subyek penelitian pada anak Tunagrahita kategori sedang di SLB Provinsi Bali terhadap keterampilan menyikat Gigi sebagaimana tabel 2 .

Tabel 2 Karakteristik subyek penelitian pada anak Tunagrahita kategori sedang di Provinsi Bali terhadap Keterampilan menyikat Gigi Tahun 2019

\begin{tabular}{|c|c|c|c|c|c|c|c|c|c|c|c|c|c|c|c|c|c|c|c|}
\hline \multirow{3}{*}{\multicolumn{2}{|c|}{ Karakteristik }} & \multirow{3}{*}{$\begin{array}{l}\text { Jumlah } \\
\text { siswa }\end{array}$} & \multicolumn{8}{|c|}{ Kelompok Perlakuan } & \multirow{3}{*}{$\begin{array}{l}\text { Jumlah } \\
\text { siswa }\end{array}$} & \multicolumn{8}{|c|}{ Kelompok Kontrol } \\
\hline & & & \multicolumn{2}{|c|}{$\begin{array}{c}\text { Sangat } \\
\text { baik }\end{array}$} & \multicolumn{2}{|c|}{ baik } & \multicolumn{2}{|c|}{$\begin{array}{l}\text { Cu- } \\
\text { kup }\end{array}$} & \multicolumn{2}{|c|}{$\begin{array}{l}\text { Perlu bimbi- } \\
\text { ngan }\end{array}$} & & \multicolumn{2}{|c|}{$\begin{array}{c}\text { Sangat } \\
\text { baik }\end{array}$} & \multicolumn{2}{|c|}{ baik } & \multicolumn{2}{|c|}{ cukup } & \multicolumn{2}{|c|}{$\begin{array}{c}\text { Perlu bimbi- } \\
\text { ngan }\end{array}$} \\
\hline & & & $f$ & $\%$ & $f$ & $\%$ & $\mathrm{f}$ & $\%$ & $\mathrm{~F}$ & $\%$ & & $\mathrm{f}$ & $\%$ & $\mathrm{f}$ & $\%$ & $\mathrm{f}$ & $\%$ & $f$ & $\%$ \\
\hline Jenis & Laki & 63 & 0 & 0 & 0 & 0 & 0 & 0 & 63 & 63 & 64 & 0 & 0 & 0 & 0 & 0 & 0 & 64 & 64 \\
\hline \multirow{2}{*}{$\begin{array}{l}\text { Kela- } \\
\text { min }\end{array}$} & Perempuan & 37 & 0 & 0 & 0 & 0 & 0 & 0 & 37 & 37 & 36 & 0 & 0 & 0 & 0 & 0 & 0 & 36 & 36 \\
\hline & Total & 100 & & & & & & & 100 & 100 & & & & & & & & 100 & 100 \\
\hline \multirow{4}{*}{$\begin{array}{l}\text { Ting- } \\
\text { kat } \\
\text { Pendi- } \\
\text { dikan }\end{array}$} & SDLB & 48 & 0 & 0 & 0 & 0 & 0 & 0 & 48 & 48 & 64 & 0 & 0 & 0 & 0 & 0 & 0 & 64 & 64 \\
\hline & SMPLB & 36 & 0 & 0 & 0 & 0 & 0 & 0 & 36 & 36 & 24 & 0 & 0 & 0 & 0 & 0 & 0 & 24 & 24 \\
\hline & SMALB & 16 & 0 & 0 & 0 & 0 & 0 & 0 & 16 & 16 & 12 & 0 & 0 & 0 & 0 & 0 & 0 & 12 & 12 \\
\hline & Total & 100 & & & & & & & 100 & 100 & & & & & & & & 100 & 100 \\
\hline
\end{tabular}

Tabel 2 menunjukkan bahwa karakteristik subyek penelitian terhadap keterampilan menyikat gigi pada anak tunagrahita kategori sedang berdasarkan jenis kelamin dan tingkat pendidikan pada kelompok perlakuan dan kelompok control semua dalam kategori perlu bimbingan. 
JURNAL KESEHATAN GIGI

(Dental Health Journal)

Vol. 7 No.1 Pebruari 2020

Tabel 3 Tingkat kebersihan gigi siswa sebelum dan setelah diberi penyuluhan kesehatan gigi dan mulut dengan menggunakan media Video dental health education anak Tunagrahita di SLB Provinsi Bali Tahun 2019

\begin{tabular}{lcccccccc}
\hline \multirow{2}{*}{$\begin{array}{c}\text { Tingkat Kebersihan } \\
\text { Gigi }\end{array}$} & \multicolumn{3}{c}{ Kelompok Perlakuan } & \multicolumn{3}{c}{ Kelompok Kontrol } \\
\cline { 2 - 10 } & \multicolumn{2}{c}{ Sebelum } & \multicolumn{2}{c}{ Sesudah } & \multicolumn{2}{c}{ Sebelum } & \multicolumn{2}{c}{ Sesudah } \\
\cline { 2 - 10 } & F & $\%$ & F & $\%$ & f & $\%$ & F & $\%$ \\
\hline Baik $(0,0-1,2)$ & 15 & 15 & 36 & 36 & 10 & 10 & 12 & 12 \\
Sedang $(1,3-3,0)$ & 68 & 68 & 56 & 56 & 86 & 86 & 87 & 87 \\
Buruk $(3,1-6,0)$ & 17 & 17 & 8 & 8 & 4 & 4 & 1 & 1 \\
\hline Jumlah & 100 & 100 & 100 & 100 & 100 & 100 & 100 & 100 \\
\hline
\end{tabular}

Tabel 3 menunjukkan bahwa tingkat kebersihan gigi siswa tunagrahita kategori sedang pada kelompok perlakuan sebelum intervensi dengan kriteria sedang sebanyak 68 (68\%) dan kriteria baik sebanyak 15 (15\%), setelah intervensi dengan kriteria sedang sebanyak 68 (56\%) dan kriteria buruk sebanyak 8 (8\%). Sedangkan pada kelompok control sebelum dilakukan intervensi dengan kriteria sedang sebanyak $86(86 \%)$ dan kriteria buruk sebanyak 4 (4\%), setelah intervensi dengan kriteria sedang sebanyak 87 $(87 \%)$ dan kriteria buruk sebanyak $1(1 \%)$.

Tabel 4 Rata rata kebersihan gigi dan mulut sebelum dan setelah diberi penyuluhan kesehatan gigi dan mulut dengan menggunakan media Video dental health education siswa Tunagrahita kategori sedang di SLB Provinsi Bali Tahun 2019

\begin{tabular}{lcc}
\hline Kelompok & \multicolumn{2}{c}{ Rata-rata kebersihan gigi dan mulut } \\
\cline { 2 - 3 } & Sebelum & Setelah \\
\hline Perlakuan & 2,26 & 1,87 \\
Kontrol & 2,00 & 1,97 \\
\hline
\end{tabular}

Tabel 4 menunjukkan bahwa rata-rata kebersihan gigi siswa tunagrahita kategori sedang di SLB Provinsi Bali untuk kelompok perlakuan sebelum intervensi 2,26 dan setelah intervensi sebesar 1,87. Sedangkan rata-rata kebersihan gigi siswa untuk kelompok kontrol sebelum intervensi 2,00 dan setelah intervensi sebesar 1,97 .

Tabel 5 Keterampilan menyikat gigi siswa sebelum dan setelah diberi penyuluhan kesehatan gigi dan mulut dengan menggunakan media Videodental health education anak Tunagrahita kategori sedang di SLB Provinsi Bali Tahun 2019

\begin{tabular}{lcccccccc}
\hline \multirow{2}{*}{ Keterampilan menyikat gigi } & \multicolumn{3}{c}{ Kelompok Perlakuan } & \multicolumn{3}{c}{ Kelompok Kontrol } \\
\cline { 2 - 9 } & \multicolumn{2}{c}{ Sebelum } & \multicolumn{2}{c}{ Sesudah } & \multicolumn{2}{c}{ Sebelum } & Sesudah \\
\cline { 2 - 9 } & $\mathrm{F}$ & $\%$ & $\mathrm{~F}$ & $\%$ & $\mathrm{f}$ & $\%$ & $\mathrm{~F}$ & $\%$ \\
\hline Sangat baik (80-100) & 0 & 0 & 0 & 0 & 0 & 0 & 0 & 0 \\
Baik (70-79) & 0 & 0 & 6 & 6 & 0 & 0 & 0 & 0 \\
Cukup (60-69) & 0 & 0 & 13 & 13 & 0 & 0 & 4 & 4 \\
Perlu Bimbingan $(<60)$ & 100 & 100 & 81 & 81 & 100 & 100 & 96 & 96 \\
\hline & 100 & 100 & 100 & 100 & 100 & 100 & 100 & 100 \\
\hline
\end{tabular}


JURNAL KESEHATAN GIGI

(Dental Health Journal)

Vol. 7 No.1 Pebruari 2020

Tabel 5 menunjukkan bahwa keterampilan siswa dalam menyikat gigi sebelum dilakukan intervensi pada kelompok perlakuan $100(100 \%)$ perlu bimbingan, sesudah intervensi 6 (6\%) kategori baik, 13 siswa kategori cukup dan 81(81\%) perlu bimbingan orang dan setelah diberi penyuluhan kesehatan gigi dan mulut. Keterampilan menyikat gigi siswa sebelum diberi penyuluhan kesehatan gigi dan mulut pada kelompok kontrol yaitu 100 orang (100\%) perlu bimbingan. Sedangkan pada kelompok kontrol tingkat kebersihan gigi siswa pada akhir penelitian dilakukan evaluasi kategori cukup sebanyak 4 orang (4\%) dan perlu bimbingan sebanyak 96 orang (94\%).

\section{Hasil analisis}

1) Uji normalitas data

Uji Normalitas data dilakukan dengan uji statistik Kolmogorov semirnov.

Hasil uji normalitas terlihat pada tabel 6 sebagai berikut :

Tabel 6 Hasil Uji Normalitas Variabel

\begin{tabular}{llcccc}
\hline No & \multicolumn{1}{c}{ Variabel } & N & $\begin{array}{c}\text { Deviasi } \\
\text { Standar }\end{array}$ & Signifikansi & Kesimpulan \\
\hline 1 & OHI-S Perlakukan Pre & 100 & 2.2551 & 0,000 & Tidak Normal \\
2 & OHI-S Perlakukan Post & 100 & 1.8710 & 0,000 & Tidak Normal \\
3 & OHI-S Kontrol Pre & 100 & 1.9991 & 0,000 & Tidak Normal \\
4 & OHI-S Kontrol post & 100 & 1.9769 & 0,000 & Tidak Normal \\
5 & Keterampilan Klp.Perlakukan Pre & 100 & 12.03278 & 0,000 & Tidak Normal \\
6 & Keterampilan Klp. Perlakuakn Post & 100 & 18.51965 & 0,000 & Tidak Normal \\
7 & Keterampilan Klp. Kontrol Pre & 100 & 12.76230 & 0,000 & Tidak Normal \\
8 & Keterampilan Klp. Kontrol Post & 100 & 13.59627 & 0,000 & Tidak Normal \\
\hline
\end{tabular}

Tabel 6 menunjukkan bahwa hasil Uji normalitas variabel kelompok perlakuan maupun kelompok kontrol sebelum dan sesudah intervensi didapatkan nilai sig $=$ 0.000 lebih kecil dari 0,05. Hasil ini menunjukkan semua data terdistribusi tidak normal. Sehingga analisis uji beda yang dipergunakan adalah Wilcoxon Signed Rank Test untuk uji data sampel berhubungan dan Uji Ancova untuk data dua sampel tidak berhubungan (Santoso, 2005).

2). Analisis keterampilan dan kebersihan gigi kelompok perlakukan sebelum dan sesuah intervensi

Tabel 7 Hasil Analisis Wilcoxon Signed Rank Test Keterampilan dan Kebersihan Gigi Responden Kelompok Perlakukan Sebelum dan Sesudah Diberikan Intervensi

\begin{tabular}{llllc}
\hline OHI-S & & & & \\
\cline { 1 - 1 } & Kelompok & & & Asymp. Sig (2-tailed) \\
& $\begin{array}{l}\text { Perlakukan } \\
\text { Pre-Post }\end{array}$ & & \\
& Keterampilan & & -8.264 & 0.000 \\
Kebersihan Gigi & & -7.534 & 0.000 \\
\hline
\end{tabular}


Tabel 7 menunjukkan bahwa hasil analisis didapatkan nilai $p$ value (Asymp.sig 2 tailed)sebesar 0,000 lebih kecil dari 0,05 yang berarti ada perbedaan bermakna (signifikan) keterampilan dan kebersihan gigi responden sebelum dan sesudah dilakukan intervensi

Tabel 8 Hasil Analisis Wilcoxon Signed Rank test Keterampilan dan Kebersihan Gigi pada Kelompok Kontrol Sebelum dan Sesudah Intervensi

\begin{tabular}{llccc}
\hline \multicolumn{1}{c}{ OHI-S } & & & \\
& $\begin{array}{l}\text { Kelompok } \\
\text { Kontrol } \\
\text { Pre-Post }\end{array}$ & & & Asymp. Sig (2-tailed) \\
& & & 0.000 \\
Keterampilan & -6.828 & & 0.587 \\
\hline
\end{tabular}

Tabel 8 menunjukkan bahwa hasil uji statistik Wilcoxon Signed Rank testp value (Asymp.sig 2 tailed) pada kelompok kontrol nilai keterampilan sebesar 0,000 dan nilai kebersihan gigi sebesar 0.587. lebih besar dari batas kritis penelitian 0.05 berarti tidak ada perbedaan yang bermakna kebersihan gigi dan mulut responden kelompok kontrol sebelum dan sesudah dilakukan intervensi.
3). Analisis keterampilan dan kebersihan gigi kelompok perlakukan dengan kelompok kontrol sesudah intervensi dengan uji MannWhitney test. Hasil uji Mann-Whitney test terlihat pada tabel 9 sebagai berikut :

Tabel 9 Hasil Analisis Mann Whitney Test OHI-S Responden Kelompok Perlakuan dan kelompok Kontrol Setelah diberikan Intervensi

\begin{tabular}{lcc}
\hline \multicolumn{1}{c}{ Uji } & Keterampilan & Kebersihan Gigi \\
\hline Mann-Whitney U & 3063.500 & 2430.500 \\
Wilcoxon W & 8113.500 & 7480.500 \\
Z & -4.783 & -6.551 \\
Asymp.Sig.(2-tailed) & 0.000 & 0.000 \\
\hline
\end{tabular}

Tabel 9 menunjukkan nilai sig sebesar 0.000 lebih kecil dari 0.05 berarti ada perbedaan yang bermakna baik keterampilan

\section{Pembahasan}

Karakteristik subyek penelitian pada anak Tunagrahita kategori sedang di SLB Provinsi Bali berdasarkan jenis kelamin dan tingkat pendidikan Tahun 2019. Berdasarkan maupun kebersihan gigi dan mulut pada kelompok perlakukan dengan kelompok kontrol setelah diberikan intervensi

deskripsi karakteristik subyek penelitian menunjukkan bahwa anak Tunagrahita kategori sedang di SLB Provinsi Bali yang berjenis kelamin laki-laki sebanyak 105 $(52,5 \%)$ lebih banyak dibandingkan dengan dengan siswa perempuan sebanyak 95 
JURNAL KESEHATAN GIGI

(Dental Health Journal)

Vol. 7 No.1 Pebruari 2020

(347,5\%). Sedangkan karakteristik berdasarkan tingkat pendidikan menunjukkan bahwa tingkat pendidikan anak Tunagrahita kategori sedang di SLB Provinsi Bali paling banyak tingkat SDLB sebanyak 109 orang $(54,5 \%)$ dan paling sedikit tingkat SMALB sebanyak 30 orang $(15 \%)$.

Tingkat kebersihan gigi siswa sebelum dan setelah diberi penyuluhan kesehatan gigi dan mulut dengan menggunakan media Videodental health education anak Tunagrahita kategori sedang di SLB Provinsi Bali. Hasil pemeriksaan kebersihan gigi dan mulut siswa tunagrahita di SLB Provinsi Bali pada kelompok perlakuan sebelum intervensi paling banyak dengan kategori sedang 68 orang (68\%) dan pada kelompok kontrol paling banyak juga dengan kategori sedang 86 orang $(86 \%)$. Setelah intervensi tingkat kebersihan gigi pada kelompok perlakuan dengan kategori sedang sebanyak 56 orang (56\%), pada kelompok control sebanyak 87 orang (87\%). Hasil penelitian ini menunjukkan bahwa kategori tingkat kebersihan gigi siswa tunagrahita pada kelompok perlakuan maupun pada kelompok control termasuk dalam kategori sedang. Hal ini mungkin disebabkan pada anak tunagrahita sedang masalah menyikat gigi merupakan masalah yang cukup komplek dalam hal bina diri dimana anak tunagrahita sedang mengalami kesulitan dan tergantung dengan bantuan orang lain dalam menyikat gigi. Anak tuna grahita memiliki keterbelakangan mental maka merupakan kelompok rawan baik dalam bidang gizi maupun dalam bidang kesehatan gigi dan mulut. Hasil penelitian menunjukkan bahwa semakin rendah tingkat kecerdasan penderita tuna grahita akan semakin buruk kebersihan gigi dan mulutnya ${ }^{7}$.

Rata rata kebersihan gigi dan mulut sebelum dan setelah diberi penyuluhan kesehatan gigi dan mulut dengan menggunakan media Video dental health education anak Tunagrahita kategori sedang di SLB Provinsi Bali Tahun 2019. Rata rata kebersihan gigi pada kelompok perlakuan sebelum dilakukan intervensi 2,26 dan setelah intervensi 1,87. Pada kelompok kontrol ratarata kebersihan gigi sebesar 2,00 dan setelah intervensi 1,97. Hasil penelitian ini menunjukkan bahwa rata-rata tingkat kebersihan gigi pada anak tunagrahita kategori sedang di SLB Provinsi Bali Tahun 2019 melebihi $\mathrm{t}$ indikator WHO untuk tahun 2020 untuk kebersihan gigi (OHI-S) yaitu dengan target $\leq 1,2^{3}$. Hal ini mungkin disebabkan karena anak tunagrahita kategori sedang merupakan salah satu anak berkebutuhan khusus yang mengalami keterlambatan dalam belajar yang kecerdasannya dibawah rata-rata anak pada umumnya. Anak tunagrahita memiliki kekurangan dan keterbatasan mental maupun fisik untuk melakukan pembersihan gigi sendiri yang optimal sehingga sulit dalam menurunkan nilai $O H I-S$ atau kebersihan gigi dan mulutnya.

Keterampilan menyikat gigi siswa sebelum dan setelah diberi penyuluhan kesehatan gigi dan mulut dengan menggunakan media Videodental health education anak Tunagrahita di SLB Provinsi Bali Tahun 2019. Keterampilan menyikat gigi siswa tunagrahita kategori sedang pada kelompok perlakuan sebelum intervensi 100 orang $(100 \%)$ termasuk dalam kategori perlu bimbingan, setelah intervensi dengan kategori baik sebanyak 6 orang $(6 \%)$, kategori cukup sebanyak 13 orang (13\%), dan sebanyak 81 orang (81\%) kategori perlu bimbingan. Keterampilan menyikat gigi siswa tunagrahita kategori sedang pada kelompok kontrol sebelum intervensi 100 orang (100\%) termasuk dalam kategori perlu bimbingan, setelah intervensi dengan kategori cukup sebanyak 4 orang (4\%), dan sebanyak 96 orang (96\%) kategori perlu bimbingan. Berdasarkan hasil penelitian ini, keterampilan menyikat gigi pada siswa tunagrahita kategori sedang pada kelompok perlakuan sebelum intervensi 100 orang (100\%) termasuk dalam kategori perlu bimbingan dansetelah intervensi terjadi peningkatan yaitu dengan kategori baik sebanyak 6 orang 
JURNAL KESEHATAN GIGI

(Dental Health Journal)

Vol. 7 No.1 Pebruari 2020

(6\%), kategori cukup sebanyak 13 orang (13\%), dan masih 81 orang $(81 \%)$ dengan kategori perlu bimbingan. Hal ini menunjukkan anak tunagrahita kategori sedang yang kurang mampu mempelajari pelajaran-pelajaran akademik seperti membaca, menulis dan berhitung namun masih dapat dididik untuk mengurus diri sendiri atau dengan pembelajaran bina diri. Keterampilan menolong diri sendiri (self help skills) dalam kehidupan sehari hari bagi anak tunagrahita kategori sedang membutuhkan pengajaran dan pemberian stimulus seperti latihan-latihan secara terus menerus, khususnya dalam keterampilan menyikat gigi.

Analisis keterampilan menyikat gigi dan kebersihan gigi kelompok perlakukan sebelum dan sesudah intervensi digunakan dengan uji statistic Wilcoxon Signed Rank test. Hasil uji statistilc Wilcoxon Signed Rank Test menunjukkan bahwa hasil analisis didapatkan nilai $p$ value (Asymp.sig 2 tailed) sebesar 0,000 lebih kecil dari 0,05 yang berarti ada perbedaan bermakna (signifikan) keterampilan dan kebersihan gigi responden sebelum dan sesudah dilakukan intervensi. Tabel 9 menunjukkan hasil uji statistik Wilcoxon Signed Rank testp value (Asymp.sig 2 tailed) pada kelompok kontrol nilai keterampilan sebesar 0,000 dan nilai kebersihan gigi sebesar 0.587 , lebih besar dari batas kritis penelitian 0.05 berarti tidak ada perbedaan yang bermakna kebersihan gigi dan mulut responden kelompok kontrol sebelum dan sesudah dilakukan intervensi. Hasil Analisis Mann Whitney Test OHIS Responden Kelompok Perlakuan dan kelompok Kontrol Setelah diberikan Intervensi, nilai sig sebesar 0.000 lebih kecil dari 0.05 berarti ada perbedaan yang bermakna baik keterampilan maupun kebersihan gigi dan mulut pada kelompok perlakukan dan kelompok kontrol setelah diberikan intervensi. Hasil penelitian ini sesuai dengan penelitian yang dilakukan oleh Gigih Putriani (2016), hasil penelitiannya menunjukkan adanya peningkatan keterampilan menyikat gigi pada anak tunagrahita kategori sedang ${ }^{1}$.

\section{Simpulan}

Berdasar hasil penelitian dan pembahasan terdapat perbedaan yang bermakna baik keterampilan menyikat gigi maupun tingkat kebersihan gigi dan mulut pada kelompok perlakukan dengan kelompok kontrol setelah diberikan intervensi yang ditunjukkan dengan nilai sig sebesar 0.00 lebih kecil dari 0.05. Sehingga dapat dibuat simpulan yaitu : penggunaan media video dental health education bermakna dalam meningkatkan keterampilan menyikat gigi dan kebersihan gigi pada siswa tunagrahita kategori sedang di SLB Provinsi Bali tahun 2019.

\section{Daftar Pustaka}

1. Gigih Putriani (2016), Peningkatan Upaya Pembelajaran Bina Diri Menggosok Gigi melalui Media Video Animasi pada Anak Tunagrahita Kategori Sedang Kelas IV SDLB di SLB Negeri Pembina, Yogyakarta, Journal Student uny.ac.id

2. Kementerian Kesehatan RI., 2013, Riskesdas, Jakarta, Badan Penelitian dan Pengembangan Kesehatan

3. Kementerian Kesehatan ,2012, Pedoman Usaha Kesehatan Gigi Sekolah (UKGS), Jakarta

4. Mumpuniarti. 2007, Pendekatan Pembelajaran bagi Anak Hambatan Mental, Yogyakarta, Kawan Publisher K; $\mathrm{N} ;$ KHHK

5. Kemenkes R.I. (2013). Riset Kesehatan Dasar 2013, Jakarta, Dirjen Bina Upaya Kesehatan Kemenkes RI.

6. Novitasari, 2011, Upaya meningkatkan Keterampilan Menggosok Gigi melalui Video pada Anak Tunagrahita Sedang, Padang, Jurnal Ilmiah Pendidikan Khusus 
7. Nurdin dan Boedihardjo, 1986, Perilaku kesehatan gigi Penderita Tunagrahita, Studi pada SLB Taman Pendidikan dan Asuhan Bagian C Jember, Majalah Ilmiah Kedokteran Gigi, Edisi Khusus Forum Ilmiah VII, Jember, FKG Universitas Jember

8. Nunung, Apriyanto (2012), Seluk Beluk Tunagrahita dan Strategi Pembelajarannya, Jogjakarta, Javalitera`
9. Putri, M.H., Herijulianti, E., Nurjannah, N., 2011, Ilmu Pencegahan Penyakit Jaringan Keras dan Jaringan Pendukung Gigi, Jakarta; EGC. 